\title{
Weight-Length Regressions and Growth for Two Bluegill Populations in Rhode Island
}

\author{
David H. Kesler \\ Division of Biotogical Sciences, Universiry of Michigan \\ Ann Arbor. Michigan 48709
}

\begin{abstract}
AB5TRACT Signticant diferences in weight-lengith regressons and growth were observed between popts-

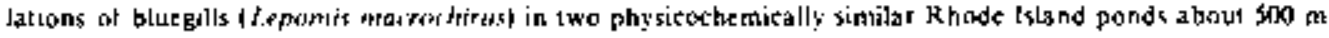
aparl. Bluegills were hedvier and gecw faster in the pond in which their densily was lower and which had a

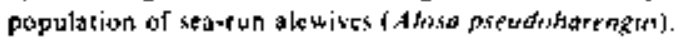

If native lishes are to be used in pond aquaculture in the United States, il is necessary that growth characteristics of local populations be krown. It is also desirable to krow how much natural variation there is belween populations of different and similar habitats.

In this study I compare the growth characteristics of the populations of bluegills (Lepomis macrochirus) inhabilıng two Rhode Island ponds, Mill Pond (MP) and Hamilton Reservoir (HR), which are within 500 m of each other. The ponds have similas physical. chemical, and biological chasacteristics (Vigerstad 1974), excegl that HR has a population of scarrun alewives (Alosta piewdollorengers)

\section{Methods}

Fish were coldected during summer 1973 with fyke nets and seines. Small fish collected in hauls with standard 3-m seines were immedialely placed in $10 \%$ formalin and weighed and measured within I weck. Samples from both ponds were analyzed at the same time to avoid differences caused by formalin preservation (Engel 1974). Rolenonc was also applied at a concentration of $0.5 \mathrm{ppm}$ to a volume of about $825 \mathrm{~m}^{3}$ previously surrounded by nels. Fish collected with cotenone and fyke nets were measured and weighed before prescrvation.

Scales were sampled from the second scale row above the lateral line at the end of the pectoral fin (Proliti 1950. location D). Scale impressions werc made on cellulose actelate strips and identilications of annuli were based on the criteria of Regier (1962). Transformations, suggested by Hennemuth (1955) because of discrepancies in sample sizes, were performed on growth jecrements derived from back. calculated lengths. Transformations were performed on growth increments only.

Slopes of the simple linear regressions of log weight on log Ienglh were compared by the analysis of covariance (Snedecor and Cochran 1967).

\section{Results and Discussion}

The simple linear body-scale regressions calculated for bluegills from HR and MP in July and October are given in Table I. Because the variances of the back-calculated lengths were rol equal (Frax-test. Sokal and Rohli 1969), I used an appropriale i-test (Sokal and Rohlf 1969) to compate lengths of bluegills from $H R$ and MP for each year class (Table 2). With one exceprion. back-calculated lengths and lengths al capture of bluegills were greater for bluegills in HR than for fish in MP. and were significanlly greater in recenl years. When growth increments of fish from $H R$ and MP in their second summer were compared, fish from $\mathbf{H R}$ had significantly grealer growth ircrements than did MP Tish in $1967.1972(t=3.49 ; \mathrm{d} t=5 ; \mathrm{P}<0.025)$. Growth increments for fish of older age classes were not signilicanuly different.

Yon Bertalanffy growh equations for tish 3-7 years old, calculated from the mean back-calculated length data (Table 2), were

$$
\begin{array}{ll}
\text { Mill Pond: } & P_{\mathrm{t}}=18.3[1+-0.61 \%(1.34)] \\
\text { Hamilton Reservoir: } & f_{\mathrm{t}}=26.7[1-0.233(t+0.16)]
\end{array}
$$

indicating that $H R$ bluegills were ultimalely longer $(26.7 \mathrm{~cm})$ and approached this lergth faster than did the MP blutgills.

To prevent size-class damisation of weight-length regressions, I established I9 length intervals for MP issh and 20 for HR tish. In early July the bluegil] weight-iength regression equations ( $\mathrm{N}=129$ [ish) were

$$
\begin{array}{ll}
\text { Mill Pond: } & \log W=4.439+2.877 \log \mathrm{L} \\
\text { Hamilton Reservoif: } & \log W=4.808+3.066 \log \mathrm{L} .
\end{array}
$$

where $W=$ weight in grams and $L=$ lotal iength in mijhmeters. Sajla and Horton (1957) reported a similar regression equation $(\log W=-4.5172+2.9238 \log I$ I) for Rhode Island bluegidls. The regression equations for fish 
Table 1. Simple tinear body-srale regressions for bluegils from Hamithon Resenoir (HR) and Mill Pond (MP). Rhode Istand, collected in July and Octoher 1973, where $Y=$ wotal tenyth in rensimesers and $X$ = scale radiss in milfimerers.

\begin{tabular}{|c|c|c|c|c|c|c|}
\hline Sample size & Month & Location & $\mathbf{r}^{2}$ & $\begin{array}{c}\text { Siandard errot } \\
\text { of estimate }\end{array}$ & $\bar{\gamma}$ & Equalion \\
\hline 45 & July & $\mathrm{HR}$ & 0.704 & 0.396 & 17.52 & $Y=6.194+4.349 X$ \\
\hline 要 & Judy & $M P$ & $0.7 \mathrm{BI}$ & 0.385 & 17.09 & $Y=4.0 \mathrm{kS}+4554 \mathrm{X}$ \\
\hline 74 & Ori. & $H R$ & 0.469 & 0.647 & 16.75 & $Y=4.5,54+4.100 X X$ \\
\hline 100 & Ocr. & $M P$ & 0927 & 0.355 & 12.12 & $\mathrm{Y}=2.226+5.215 \mathrm{X}$ \\
\hline
\end{tabular}

Table 2. Mean back-ratculased tengths fin millimesers) of bitugills from Mill Pand (MP) and Hamiton Reservoir (HR).

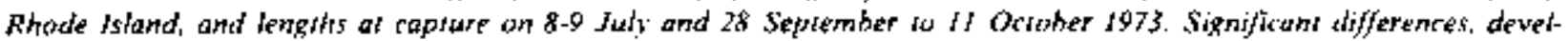
oped from t-sesss, are given b. ${ }^{*}(\mathrm{P}<0.05)$ and $* *$ ( $\left.<0.0 t\right)$.

\begin{tabular}{|c|c|c|c|c|c|c|c|c|c|c|c|c|c|c|c|c|c|c|c|c|}
\hline \multirow{3}{*}{$\begin{array}{l}\text { Year } \\
\text { class }\end{array}$} & \multicolumn{14}{|c|}{ Age class (jears) and location } & \multicolumn{4}{|c|}{ Length at taplure } & \multirow{2}{*}{\multicolumn{2}{|c|}{$\begin{array}{l}\text { Tota] } \\
\text { fish }\end{array}$}} \\
\hline & \multicolumn{2}{|c|}{1} & \multicolumn{2}{|c|}{2} & \multicolumn{2}{|c|}{3} & \multicolumn{2}{|c|}{4} & \multicolumn{2}{|c|}{5} & \multicolumn{2}{|c|}{6} & \multicolumn{2}{|c|}{7} & \multicolumn{2}{|c|}{ July } & \multicolumn{2}{|c|}{ Sepi,-Ost. } & & \\
\hline & MP & HK & $M P$ & HR & $M P$ & HR & $M P$ & $\mathbf{H R}$ & $M P$ & $\mathrm{HR}$ & MP & HR & MP & HR & MP & HK & $\mathbf{M P}^{3}$ & $H R$ & $\mathrm{MP}$ & HR \\
\hline 1967 & 39 & 42 & $T 7$ & 87 & 115 & 147 & 142 & 185 & 159 & 398 & 179 & 208 & 176 & 217 & & & I\&! & 219 & 3 & $\mathbf{I}$ \\
\hline 1968 & 38 & 39 & 76 & 98. & 115 & $144^{*}$ & 141 & 163 & 169 & 177 & 176 & $189{ }^{\circ}$ & & & 182 & $190^{\circ}$ & 180 & $197 *$ & 15 & 5 \\
\hline 1969 & 39 & 38 & II & 84 & 125 & 130 & 154 & 157 & 172 & 179 & & & & & 184 & 199 & 167 & $194^{*}$ & 33 & 24 \\
\hline 1970 & 40 & 43 & 如 & 86 & 119 & 127 & 150 & $16,50 \%$ & & & & & & & 170 & $J B J^{*+}$ & 154 & $\left.18\right|^{\star 4}$ & 47 & 29 \\
\hline 1971 & 39 & $45 * *$ & 77 & $91 \%+4$ & 122 & $149^{\circ}$ & & & & & & & & & 15] & $165^{\circ}$ & 144 & $179 * 4$ & 34 & 21 \\
\hline 1972 & 44 & $46^{*}$ & 79 & $106^{* *}$ & & & & & & & & & & & 123 & 145 & 120 & $151^{\circ+}$ & GH & 14 \\
\hline 1973 & $d 0$ & 40 & & & & & & & & & & & & & & & 78 & 96 & 50 & 3 \\
\hline Mean & 40 & $42 *$ & 78 & $94^{* \star}$ & 19 & $1.39^{\circ}$ & 147 & $168^{\circ *}$ & 164 & $185^{\circ}$ & +178 & 199 & 176 & 217 & & & & & & \\
\hline
\end{tabular}

collected in Seplember and in Oct dber were nol significantly different.

The slope of the regression equation was significantly grealer ( $F=6.7 \mathrm{I} ; \mathrm{dI}=1,37 ; \mathrm{P}<0.025)$ for fish in HR than for those in MP. Thus, HR fish not only wefe heavier than MP fish at any given length, but also increased in wejghl with increasing length at a significantly greater rate than MP fish. Condition indices (K) of both sexes were significantly grealer ( $P<0.01)$ for HR bluegilss (except young of the year).

The significantly grealer rate of weight increase with length and greater ulijmate lergth for HR bluegills suggest that HR is the better habitat for the species. Further research would be needed to determine whether factors other thar the presence of alewives caused this difference.

Density of young-of-the-year bluegitls was estimated (on the basis of rotenone application and recovery of fish h to be 2,600 figh $i$ ha in MP and 300 / ha in HR. The smallet number of bluegills in HR stuggests that less intraspecific competition occurs at the bower densily. Carciul stocking and manage. menl of farm ponds are necessary to prevent overcrowding and stunting of bluegills (Bentett et al. 1940).

This study points up the neted for careful evaluation of local conditions, cven in apparently similar habitals, before intensive aquaculture is undertaken.

\section{Acknowledgments}

I thank T. J. Vigerslad, C. R. Shoop. S. B. Saila, and W. H. Krutger of the University of Rhode Island for their assista nce, and the $R$ hode Island Fish and Wildlife Division for the use of fyke rets and rotenore.

\section{References}

Benfett. G. W.. D. H. Thempson, and S. A. Parr. 1940. Lake management regarts. 4 . A second year of Jisheries istestigations at Fork Lake, 1939. Ill. Nat. Hist. Surv, Hiol. Notes 14:1-24.

Enge1, S. 1974. Efiects of formalis and frecting on lengths, weight and condition factor of tisco and yellow perch. Trans. A m. Fish. Soc. $103-136-1] 3$

Hennemuth. R. C. 1955. Growih of ecappies. bluegill, and trasmouth in Lake Ahquabi, lowa. 1s. St, Coll. J. Sci. 30:119-137.

Proftst, M. A. 1950 . Comparative morphometry and growith of scales in the bluegill, Lapomis m. macrochirtes Rafinesque, with special etelence to related body growith. Ph.D. thesit, Universily of Michigan. Ann Arbot. 96 pp.

Kegier, H. A. 1962, Validation of the scale method for estimating sge and growth of bluegils. Trans. Am. Fish. Soc. 9l:382-374.

Saila, S. B., and IJ. Horton. 19\$? F. Fisheries inwestigations and management in Rhode [s]and dakes and ponds. R.I. Dep. Agric. Consers.. Div. Fish Game, Fish, Pub. 1: 1-134.

Snedecor. G. W., and W. G. Cochran. 1967. Siatistical methods. 10wa State Univ. Prexs. Ames. \$lo pp.

Sokal, R. R., and F. J. Rohlf. 1969 . Bjometry: the principles and pfactices of statistits in biological reseatch. Freeman and (o. San Francisco. 376 pp.

Vigerstad. T. J. 1974. Elfeets of predation by searun alewives (Atrso psethohdrengws) on the heleoplasklon tommunity of a small pond. M.S. thesis. Uasversity of Rhode Island. Kineston, R.I. $95 \mathrm{pF}$.

Acceped IS November 1977 